\title{
Restriction enzyme digestion chromosome banding in Crassostrea and Ostrea species: comparative karyological analysis within Ostreidae
}

\author{
A. Leitão, R. Chaves, S. Santos, H. Guedes-Pinto, and P. Boudry
}

\begin{abstract}
Reliable banding techniques are a major necessity for genetic research in oysters. In this study, we carried out the cytogenetic characterization of four oyster species (family Ostreidae) using restriction endonuclease treatments. Chromosomes were treated with three different restriction enzymes, stained with Giemsa, and examined for banding patterns. The following species were studied: Crassostrea gigas $(2 n=20$; total number of bands with ApaI, 74; HaeIII, 61; PstI, 76), Crassostrea angulata $(2 n=20 ;$ ApaI, 62; HaeIII, 61; PstI, 55) (subfamily Crassostreinae), Ostrea edulis $(2 n=20 ;$ ApaI, 82; HaeIII, 59; PstI, 66), and Ostrea conchaphila (2n = 20; ApaI, 68; HaeIII, 62; PstI, 69) (subfamily Ostreinae). Treatment of samples with ApaI, HaeIII, and PstI produced specific banding patterns, which demonstrates the potential of these enzymes for chromosome banding in oysters. This is of special interest, since it has been recently shown in mammalian chromosomes that restriction enzyme banding is compatible with fluorescence in situ hybridiza- tion. This study therefore provides a fundamental step in genome mapping of oysters, since chromosome banding with restriction enzymes facilitates physical gene mapping in these important aquaculture species. The analysis of the banded karyotypes revealed a greater similarity within the genera of Crassostrea and Ostrea than between them.
\end{abstract}

Key words: Ostreidae, Crassostrea, Ostrea, chromosome banding, in situ restriction enzyme banding.

Résumé : Des techniques fiables d'analyse caryotypique sont nécessaires afin de pousser plus avant la recherche génétique chez les huîtres. Dans ce travail, les auteurs ont réalisé une caractérisation cytogénétique de quatre espèces d'huîtres (famille des ostréidés) à l'aide de traitements avec des enzymes de restriction. Les chromosomes ont été traités avec trois enzymes de restriction différentes, colorés au Giemsa et examinés pour la présence de bandes. Voici les résultats pour chacune des espèces : Crassostrea gigas $(2 n=20$; nombre total de bandes avec ApaI, 74; HaeIII, 61; PstI, 76), Crassostrea angulata $(2 n=20 ;$ ApaI, 62; HaeIII, 61; PstI, 55) (sous-famille des Crassostreinae) Ostrea edulis $(2 n=20 ;$ ApaI, 82; HaeIII, 59; PstI, 66) et Ostrea conchaphila $(2 n=20 ;$ ApaI, 68; HaeIII, 62; PstI, 69) (sousfamille des Ostreinae). Les traitements avec les enzymes de restriction ont produit des bandes spécifiques, ce qui démontre l'utilité potentielle de ces enzymes pour la révélation de bandes chromosomiques chez les huîtres. Ceci est particulièrement intéressant suite à la récente démonstration, sur des chromosomes de mammifères, que la révélation des bandes résultant de ces traitements aux enzymes de restriction est compatible avec l'hybridation in situ en fluorescence. Cette étude fournit une assise importante en matière de cartographie génomique chez les huîtres puisque le marquage des chromosomes à l'aide d'enzymes de restriction facilitera la cartographie physique chez ces espèces importantes en aquaculture. L'analyse des carytoypes ainsi marqués a révélé une plus grande similarité au sein des genres Crassostrea et $O$ strea qu'entre eux.

Mots clés: Ostréidés, Crassostrea, Ostrea, marquage chromosomique, marquage in situ par digestion avec des enzymes de restriction.

[Traduit par la Rédaction]

A. Leitão. Laboratoire de Génétique et Pathologie, Station de l'Institut pour la Recherche et l'Exploitation de la Mer (IFREMER), 17390 La Tremblade, France, and Department of Genetics and Biotechnology, Centre of Genetics and Biotechnology of the University of Trás-os-Montes and Alto Douro, CGB/UTAD, P-5000-911 Vila Real, Portugal.

R. Chaves, ${ }^{1}$ S. Santos, and H. Guedes-Pinto. Department of Genetics and Biotechnology, Centre of Genetics and Biotechnology of the University of Trás-os-Montes and Alto Douro, CGB/UTAD, P-5000-911 Vila Real, Portugal.

P. Boudry. Laboratoire de Génétique et Pathologie, Station de l'Institut pour la Recherche et l'Exploitation de la Mer (IFREMER), 17390 La Tremblade, France.

${ }^{1}$ Corresponding author (e-mail: rchaves@utad.pt). 


\section{Introduction}

According to the morphologically based classification of Harry (1985), the family Ostreidae includes three subfamilies, Lophinae, Ostreinae (flat oyster species), and Crassostreinae (cupped oyster species). Recent techniques such as molecular phylogenetic analysis has provided novel insights into oyster evolution and systematics within the subfamily Ostreinae (Jozefowicz and O'Foighil 1998; O'Foighil and Taylor 2000) and the subfamily Crassos- treinae (Littlewood 1994; Lapègue et al. 2002; Boudry et al. 2003). Karyological analysis among cupped (Ladron de Guevara et al. 1996; Leitão et al. 1999a) and flat oysters (Leitão et al. 2002) has proven complementary to these ap- proaches and has provided additional evolutionary infer- ences. However, no detailed cytogenetical analysis was performed until now between these two subfamilies.

The genus Crassostrea (subfamily Crassostreinae) and Ostrea (subfamily Ostreinae), which include most of the commercially important oyster species, share a common diploid chromosome number of $2 n=20$, and their karyotypes include almost only metacentric and submetacentric chromosomes (Thiriot-Quiévreux 2002). Interspecific karyological differences consisted of the occurrence and differing proportions of these morphological types.

The precise identification of individual chromosomes and of particular regions of the chromosomes in these two subfamilies is necessary to elucidate the karyotype evolution and phylogenetic relationships within the family Ostreidae. The first studies, on bivalve chromosomes, mainly concerned data on chromosome number and gross morphology (Longwell et al. 1967; Ahmed 1973). Later, the development of banding techniques, which allowed chromosome identification in karyotypes, began to be applied in bivalves (for a review, see Thiriot-Quiévreux 1994). Recent molecular (e.g., fluorescence in situ hybridization (FISH)) and banding techniques (e.g., $\mathrm{G}$ or $\mathrm{C}$ banding) have contributed to a better identification of whole chromosomes or specific parts of them, allowing more reliable intra- or interspecific comparisons of genetic resources for taxonomical or chromosomal manipulation purposes (e.g., Mendez et al. 1990; Insua and Méndez 1998; Wang and Guo 2001; for a review, see ThiriotQuiévreux 2002).

However, the classical cytogenetic technique used until now for the identification of all individual chromosomes in karyotypes of oyster species, G banding (Leitão et al. 1999b), presents some disadvantages such as limited reproducibility, large time investment required, and the fact the banding is often lost during the in situ hybridization (FISH) procedure.

In higher vertebrates including humans, a variety of techniques have been developed to facilitate precise identification of individual chromosomes (Babu 1988). In situ digestion with restriction endonucleases (REs), which cleave DNA at specific target sequences, has been shown to produce consistent banding patterns in fixed mammalian and insect chromosomes (Marchi and Mezzanote 1988). However, this technique has rarely been applied to bivalves, as only two species have been investigated so far. Martinez-Lage et al. (1994) and Gajardo et al. (2002) have obtained specific chromosome bands by digestion with REs in the mussel
Mytilus galloprovincialis and the scallop Argopecten purpuratus, respectively.

RE banding presents a major advantage, since it has been recently shown in mammals that restriction enzyme banding is compatible with FISH (Chaves et al. 2002). Moreover, the combined use of different REs can also be useful in the detection of different classes of heterochromatin not revealed by standard banding techniques.

In the present study, we applied RE banding to oysters for the first time. We applied three REs, ApaI, HaeIII, and PstI, to fixed metaphase chromosomes of Crassostrea gigas Thunberg and Crassostrea angulata Lamarck (belonging to the subfamily Crassostreinae) and of Ostrea edulis Linné and Ostrea conchaphila Carpenter (belonging to the subfamily Ostreinae) to evaluate the potential of this tool in genetic research in oysters.

\section{Material and methods}

\section{Biological material}

Specimens of the Californian Olympia oyster $O$. conchaphila, parental oysters $\left(\mathrm{G}_{0}\right)$, were imported from the Pacific Institute (Olympia, Washington). Oysters were strictly confined to the quarantine facilities of the IFREMER hatchery of La Tremblade, Charente-Maritime, France, according to ICES recommendations. After reproduction, the progeny $\left(\mathrm{G}_{1}\right)$ was used in this experiment. Specimens of $C$. gigas were collected from the Seudre estuary, Charente-Maritime, France, where this species was introduced from Japan (Grizel and Héral 1991) and is currently farmed on a large scale. Specimens of $C$. angulata were collected in Setubal bay (Portugal) and then acclimated at the IFREMER hatch- ery. Specimens of $O$. edulis were produced at the IFREMER hatchery where each taxa was reared before the experiment.

\section{Chromosome preparation}

Whole juvenile animals (approximately $2.5 \mathrm{~cm}$ length) were incubated for $7-9 \mathrm{~h}$ in a $0.005 \%$ solution of colchicine in seawater. Because cell cultures are not yet available for molluscs, we used growing somatic tissues such as gills as a source of mitoses. After dissection, the gills were treated for $30 \mathrm{~min}$ in $0.9 \%$ sodium citrate in distilled water. The mate- rial was fixed in a freshly prepared mixture of absolute alco- hol and acetic acid (3:1) with three changes of 20 min each. Fixed pieces of gill from each individual were dissociated in $50 \%$ acetic acid with distilled water solution. The suspen- sion was dropped onto heated slides at $44{ }^{\circ} \mathrm{C}$ and air dried (ThiriotQuiévreux and Ayraud 1982). The slides were kept at -20 ${ }^{\circ} \mathrm{C}$ until further used.

\section{In situ RE digestion}

Slides were aged for $6 \mathrm{~h}$, in a dry incubator at $65^{\circ} \mathrm{C}$, before RE treatment.

The REs used (ApaI, HaeIII, and PstI) were diluted in the buffers indicated by the manufacturer (Invitrogen, Life Technologies), and final concentrations of $30 \mathrm{U}$ were obtained per $100 \mu \mathrm{L}$. The $100 \mu \mathrm{L}$ of each one of these solutions was placed on slides and covered with coverslips. These slides were incubated in a humid chamber for $16 \mathrm{~h}$ at $37^{\circ} \mathrm{C}$. Control slides were subjected to the same treatment as described above but incubated only with buffer. The slides were then 
washed in distillated water, air-dried, and stained with Giemsa (1\% solution, diluted in phosphate buffer at $\mathrm{pH} 6.8$ ).

\section{Microscopy and image processing}

Images of metaphases of all the four species banded with each one of the three REs were acquired with a CCD camera (Axiocam, ZEISS) coupled to a ZEISS Axioplan 2 imaging microscope. Digitized photographs were printed from Adobe Photoshop (version 5.0) using only contrast and colour optimization functions that affected the whole of each image.

\section{Karyotypes analysis}

The karyotypes of the four species were organized following previously published results. The karyotype of $C$. gigas consists of 10 metacentric chromosome pairs, that of $C$. angulata has nine metacentric chromosome pairs and one submetacentric (No. 8) chromosome pair (Leitão et al. $1999 a$ ), that of $O$. edulis has five metacentric (Nos. 1, 2, 3, 5, and 6) and five submetacentric (Nos. 4, 7, 8, 9, and 10) chromosome pairs (Thiriot-Quiévreux 1984), and the that of $O$. conchaphila includes six metacentric (Nos. 1, 2, 4, 6, 8, and 10) and four submetacentric (Nos. 3, 5, 7, and 9) chromosome pairs (Leitão et al. 2002).

We analysed for constructing the ideograms 20 cells/karyotypes of $C$. gigas, 20 cells/karyotypes of $C$. angulata, 15 cells/karyotypes of $O$. edulis, and 10 cells/karyotypes of $O$. conchaphila.

\section{Results}

All of the REs tested yielded specific banding patterns. Moreover, the banding patterns were consistent between members of homologous pairs. The in situ RE experiments performed with the three REs (ApaI, GGGCC/C; HaeIII, GG/CC; PstI, CTGCA/G) were compared with control treatments on slides from the four species. Control slides were tested with the same treatment as the in situ restriction banding slides (with the respective RE) but incubated only with buffer. In all cases, there was no banding pattern induced in the chromosomes, and all chromosomes (from the four species, with the buffers from the three REs) showed a Giemsa standard staining.

Examples of banded metaphases with the three REs are given in Fig. 1. Karyotypes with consistent banding patterns between homologous pairs are shown in Fig. 2.

All of the results are assembled and summarized in Fig. 3, which shows the haploid distribution of chromosomal bands in the four oyster species for each of the three enzymes tested. All of the enzymes tested (ApaI, HaeIII, and PstI) in the chromosomes of the four species produced a banding pattern along the length of each of the chromosomes (Fig. 3). The banding produced was sufficient to identify all chromosomes of the four species and organize their respec- tive karyotypes (Figs. 2 and 3).

All three REs used (ApaI, HaeIII, and PstI) in the chromosomes of the four species demonstrated interstitial, centromeric, and telomeric bands along the chromosomes. The REs used did not apparently induce the formation of Gor $\mathrm{C}$ - like banding pattern if we compare them with previous work published on the karyotypes of the three species $C$. gigas, $C$. angulata, and $O$. conchapila, where classical cytogenetical banding techniques ( $\mathrm{G}$ and $\mathrm{C}$ banding) were performed (Leitão et al. 1999b, 2002).

Figure 4 is a schematic representation of the in situ restriction banding patterns obtained for the three REs in each one of the four oyster species. For the construction of the ideograms, we only described the number of bands and each band's relative position; the intensity of the bands was not considered. The intensity of the bands in RE treatments seems to be related to the type of counterstain used (e.g., Giemsa or fluorochroms) (Gosálvez et al. 1991). Further- more, there is no agreement with the correlation between the loss of DNA extraction (after RE treatment) and the reduc- tion in the staining (Gosálvez et al. 1991). Several authors demonstrate that the loss of DNA after a RE digestion can increase the capacity of the stain to bind to a specific chro- mosome region (Gonsálvez et al. 1991; Nieddu et al. 1999). Therefore, it seems reasonable not to consider intensity of bands in the construction of ideograms but only their pres- ence and position (see Fig. 4).

The comparison of the ideograms (and restriction in situ chromosomes, cf. Fig. 3) between $C$. gigas and $C$. angulata using the three different REs (Fig. 4) demonstrates that this technique is reproducible. All corresponding chromosomes between two species (e.g., chromosome 1 from $C$. gigas and chromosome 1 from $C$. angulata; chromosome classification from the previous standardization of the respective karyotypes (see Leitão et al. 1999b)) showed a different banding pattern with all three enzymes. Moreover, chromosome 10, the only chromosome that showed similar longitudinal differentiation between $C$. gigas and $C$. angulata in all three REs tested, exhibits its own banding pattern for each enzyme in each species (Fig. 4).

The general analysis of the in situ restriction banding patterns between the chromosomes of $C$. gigas and $C$. angulata (Fig. 4) reveals that PstI induces the better banding pattern distinction between the two species karyotypes followed by ApaI and finally HaeIII. PstI induced a very different banding pattern both in terms of bands relative position and in terms of the total number of bands observed in the two ideograms.

The banding pattern comparison between $O$. edulis and $O$. conchaphila (Figs. 3 and 4) demonstrated that with all three REs tested, the respective in situ restriction banding pattern is characteristic for each enzyme and species. Nevertheless, ApaI seems to be the best enzyme for a easy identification of the two individual karyotypes.

The analysis of each individual chromosome in $O$. edulis and $O$. conchaphila (Figs. 3 and 4) reveals that using HaeIII and PstI REs, chromosomes 8, 9, and 10 present the closest in situ restriction banding patterns (Figs. 3 and 4).

Finally, the karyotypes and ideograms (Figs. 3 and 4) were very different for each genus. Moreover, any one of the three REs used could be adequate for the identification of the karyotypes of species from the two genera.

\section{Discussion}

REs have been used on chromosomes of several species (from plants to animals) to produce in situ cleavage of the DNA molecule housed in the chromosome, which is visible as a longitudinal differentiation of the chromosomes or a 
banding pattern (in situ restriction banding pattern; for a review, see Gosálvez et al. 1997). This technique has been used in several applications from clinical (human chromosomes; Babu 1988) to more fundamental studies of chromosome evolution (Pieczarka et al. 1998) and chromosome structure (Mezzanote et al. 1985; Gosálvez et al. 1991), among others (Chaves et al. 2000). In bivalves, this technique has only been applied in two bivalve species, M. galloprovincialis (Martinez-Lage et al. 1994) and A. purpuratus (Gajardo et al. 2002). In both cases, specific chromosome bands were obtained after digestion with REs; however, no chromosome evolution studies had yet been performed with this technique in this group.

The application, for the first time in this study, of the three REs ApaI, HaeIII, and PstI to the chromosomes of four oyster species, C. gigas, C. angulata (subfamily Crasso- streinae), $O$. edulis, and $O$. conchaphila (subfamily Ostreinae), produced specific banding patterns. All three REs induced an in situ restriction banding pattern suitable for the organization of the respective karyotypes (Figs. 1-3) in the chromosomes of the four species analysed. Moreover, the banding pattern obtained is consistent between chromosomes homologous pairs (Fig. 2). Therefore, this technique is demonstrated to be a reliable and a more expeditious technique (compared with the classical banding techniques) for oyster chromosome banding.

This is far more important because until now, only one technique, $\mathrm{G}$ banding, allowed the identification of all individual chromosomes in oysters and consequently the preparation of accurate karyotypes and description of the respective ideograms. In oysters, very few studies were performed with $\mathrm{G}$ banding: in Crassostrea virginica (Rodri- guez-Romero et al. 1979; Leitão et al. 1999b) and in C. gigas and C. angulata (Leitão et al. 1999b). This is probably due to the several difficulties with its application, men- tioned previously in the Introduction.

As seen in the Results, the application of the REs ApaI, HaeIII, and PstI to the four oyster species studied provided three new different patterns of chromosome identification (one for each restriction enzyme) for each of the four species.

The in situ restriction banding technique also presents other advantages, since it can be used simultaneously with FISH techniques (Chaves et al. 2002). Furthermore, as tissue culture protocols are not yet available for oysters, the chromosomes are prepared directly from the animals and are of poor morphology. The in situ restriction banding technique preserves the morphology of chromosomes better (compared with other classical banding methods), representing an additional advantage for the identification of oyster chromosomes, especially when using additional techniques such as FISH and C banding (Chaves et al. 2002).

The comparative analysis between the RE ideograms from $C$. gigas and $C$. angulata reveals different restriction in situ banding patterns for the same RE in analysis and among different REs (Fig. 4). The exception was chromosome 10, which showed similar longitudinal differentiation, for the same RE, between the two species being compared (Fig. 4).
The same in situ restriction banding pattern for chromosome 10 suggests a similar base composition between the respective chromosomes of the two species and therefore a com mon origin. Consequently, chromosome 10 seems to be the chromosome most conserved between $C$. gigas and $C$. angulata. On the other hand, the general dissimilar restriction in situ banding pattern between $C$. gigas and $C$. angulata suggests that these species are two different cytotypes. This is of special interest, since these two taxa have often been considered to be the same species (Menzel 1974), can hybridize with not apparent pre- or postzygotic reproductive barriers (Huvet et al. 2001; Huvet et al. 2002), and have only recently been differentiated by mitochondrial DNA analysis (Boudry et al. 1998; O'Foighil et al. 1998; Boudry et al. 2003) and karyotype analysis (Leitão et al. 1999a, 1999b).

The comparison of the ideograms from $O$. edulis and $O$. conchapila (Fig. 4) reveals a higher degree of divergence than that between $C$. gigas and $C$. angulata (Fig. 4). In addi- tion, only chromosomes 8,9 , and 10 from $O$. edulis and $O$. conchapila with the REs HaeIII and PstI showed a more related in situ restriction banding pattern. These results are in accordance with our previous results (Leitão et al. 2002). Additionally, they are also in accordance with phylogenetic data showing that there is a higher phylogenetic distance between $O$. edulis and $O$. conchaphila (7.4\% DNA sequence divergence for 16S; Jozefowicz and O'Foighil 1998) than between $C$. gigas and $C$. angulata $(0.5-1 \%$ DNA sequence divergence for $16 \mathrm{~S}$; Boudry et al. 2003).

Our results also suggest that for karyotype identification between $C$. gigas and $C$. angulata, PstI is the best RE and for chromosomes from $O$. edulis and $O$. conchapila, the RE most adequate should be ApaI.

The general evaluation of the comparative analysis among all restriction in situ ideograms from the studied four species showed different banding patterns (more dissimilar than the ones from classical banding techniques). These results support the hypothesis that the chromosomes and karyotypes of Crassostrea and Ostrea species evolved by chromosomal rearrangements. Since the fundamental chromosome number $(2 n=20)$ has been previously been shown to be the same and the chromosome form is similar among the species of Crassostrea and Ostrea (for a review, see Thiriot-Quiévreux 2002) and, in parallel, we have shown that the in situ restriction banding patterns are different, it seems reasonable to assume that chromosomal rearrangements, such as inversions or reciprocal translocations, explain the chromosome and karyotype evolution of these two genera.

Besides the value in offering a new approach to specific problems in oyster taxonomy, this technique may also be very useful in other studies of more economic or ecological importance. The use of REs could, for instance, provide a more rapid method of identification of the missing chromosomes in the study of the economically important aneuploidy phenomenon reported in oysters (Leitão et al. 2001) and also provide a very valuable technique for chro- mosome segregation studies on commercially important triploid and tetraploid oysters (Guo and Allen 1997). 
Restriction enzyme banding also has the advantage of being compatible with FISH (Chaves et al. 2002), allowing simultaneous banding and application of FISH. Moreover, this technique demands only one round of observation and minimal extra preparation steps. Consequently, the in situ restricttion banding technique will facilitate the physical gene mapping in this group.

Furthermore, the fact that each enzyme provides a differ- ent model of chromosome identification will allow the choice of the most adequate for the comparison between dif- ferent species (e.g., as seen in the Results, PstI seems to be the more adequate for the interspecifc comparison between $C$. gigas and C. angulata), for example, in hybrid studies or hybrid breeding or stock conservation programs.

The applications of restriction enzyme chromosome banding are therefore diverse and seem to offer a new approach to specific problems in oyster taxonomy and genetics.

\section{Acknowledgements}

This work was partially supported by a Portuguese grant from the Ministry of Science and Technology (FCTI) (SFRH/BPD/1582-2000). We are grateful to $S$. Lapègue and D. Cheney for supplying live $O$. conchaphila oysters, to $\mathrm{H}$. McCombie for revising the English, and to C. ThiriotQuiévreux for constructive comments.

\section{References}

Ahmed, M. 1973. Cytogenetics of oysters. Cytologia, 38: 337-346. Babu, A. 1988. Heterogeneity of heterochromatin of human chromosomes as demonstrated by restriction endonuclease treatment. In Heterochromatin: molecular and structural aspects. Edited by R.S. Verma. Cambridge University Press, New York, N.Y. pp. 250-275.

Boudry, P., Heurtebise, S., Collet, B., Cornette, F., and Gérard, A. 1998. Differentiation between populations of the Portuguese oyster, Crassostrea angulata (Lamarck) and the pacific oyster, Crassostrea gigas (Thunberg) revealed by mtDNA RFLP analysis. J. Exp. Mar. Biol. Ecol. 226: 279-291.

Boudry, P., Heurtebise, S., and Lapègue, S. 2003. Mitochondrial and nuclear DNA sequence variation of presumed Crassostrea gigas and Crassostrea angulata specimens: a new oyster species in Hong Kong? Aquaculture, 228: 15-25.

Chaves, R., Heslop-Harrison, J.S., and Guedes-Pinto, H. 2000. Centromeric heterochromatin in the cattle rob $(1 ; 29)$ translocation: $\alpha$-satellite sequences, in situ MspI digestion patterns, chromomycin staining and C-bands. Chromosome Res. 8: 621-626.

Chaves, R., Adega, F., Santos, S., Guedes-Pinto, H., and HeslopHarrison, J.S. 2002. In situ hybridization and chromosome banding in mammalian species. Cytogenet. Genome Res. 96: 113116.

Gajardo, G., Parraguez, M., and Colihueque, N. 2002. Karyotype analysis and chromosome banding of the Chilean-Peruvian Scallop Argopecten purpuratus (Lamarck, 1819). J. Shellfish Res. 21: 585-590.

Gosálvez, J., Mezzanotte, R., López-Fernández, C., et al. 1991. Selective digestion of mouse chromosomes with restriction endonucleases. II. X-ray microanalysis of Hae III-treated chromosomes. Cytogenet. Cell Genet. 56: 82-86.
Gosálvez, J., López-Fernández, C., Goyanes, V., and Mezzanotte, R. 1997. Chromosome differentiation using nucleases: an over- view. In Chromosomes today. Vol. 12. Edited by $\mathrm{N}$. Henriques- Gil, J.S. Parker, and M.J. Puertas. Chapman and Hall, London, UK.

Grizel, H., and Héral, M. 1991. Introduction into France of the Japanese oyster (Crassostrea gigas). J. Cons. Int. Explor. Mer, 47: 399-403.

Guo, X.M., and Allen, S.K. 1997. Sex and meiosis in autotetraploid pacific oyster, Crassostrea gigas (Thunberg). Ge- nome, 40: 397-405.

Harry, H.W. 1985. Synopsis of the supraspecific classification of living oysters (Bivalvia: Gryphaeidae and Ostreidae). Veliger, 28: $121-158$.

Huvet, A., Balabaud, K., Bierne, N., and Boudry, P. 2001. Microsatellite analysis of 6-hour-old embryos reveals no preferential intraspecific fertilization between cupped oysters Crassostrea gigas and Crassostrea angulata. Mar. Biotechnol. 3: $448-453$.

Huvet, A., Gérard, A., Ledu, C., Phélipot, P., Heurtebise, S., and Boudry, P. 2002. Is fertility of hybrids enough to conclude that the two oysters Crassostrea gigas and Crassostrea angulata are the same species? Aquat. Living Resour. 15: 45-52.

Insua, A., and Méndez, J. 1998. Physical mapping and activity of ribosomal RNA genes in mussel Mytilus galloprovincialis. Hereditas, 128: 189-194.

Jozefowicz, C.J., and O'Foighil, D. 1998. Phylogenetic analysis of Southern Hemisphere flat oysters based on partial mitochondrial 16S rDNA gene sequences. Mol. Phylogenet. Evol. 10: 426435 .

Ladron de Guevara, B., Winkler, F., Rodriguez-Romero, F., and Palma-Rojas, C. 1996. Comparative karyology of four American oyster species. Veliger, 39: 260-266.

Lapègue, S., Boutet, I., Leitão, A., Heurtebise, S., Garcia, P., Thiriot-Quiévreux, C., and Boudry, P. 2002. Trans-Atlantic distribution of a mangrove oyster species revealed by $16 \mathrm{~S}$ mtDNA and karyological analyses. Biol. Bull. 202: 232-242.

Leitão, A., Boudry, P., Labat, J.P., and Thiriot-Quiévreux, C. $1999 a$. Comparative karyological study of cupped oyster species. Malacologia, 41: 175-186.

Leitão, A., Thiriot-Quiévreux, C., Boudry, P., and Malheiro, I. 1999b. A "G" chromosome banding study of three cupped oyster species: Crassostrea gigas, Crassostrea angulata and Crassostrea virginica (Mollusca: Bivalvia). Genet. Sel. Evol. 31: 519-527.

Leitão, A., Boudry, P., and Thiriot-Quiévreux, C. 2001. Evidence of differential chromosome loss in aneuploid karyotypes of the Pacific oyster Crassostrea gigas. Genome, 44: 735-737.

Leitão, A., Chaves, R., Santos, S., Boudry, P., Guedes-Pinto, H., and Thiriot-Quiévreux, C. 2002. Cytogenetic study of Ostrea conchaphila (Mollusca: Bivalvia) and comparative karyological analysis within Ostreinae. J. Sellfish Res. 21: 685-690.

Littlewood, D.J.T. 1994. Molecular phylogenies of cupped oysters based on partial 28S rRNA gene sequences. Mol. Phylogenet. Evol. 3: 221-229.

Longwell, A.C., Stiles, S.S., and Smith, D.G. 1967. Chromosome complement of the American oyster Crassostrea virginica as seen in meiotic and cleaving eggs. Can. J. Genet. Cytol. 9: 845856.

Marchi, A., and Mezzanote, R. 1988. Restriction endonuclease digestion and chromosome banding in the mosquito, Culiseta longiareolata (Diptera: Culicidae). Heredity, 60: 21-26.

Martinez-Lage, A., Gonzalez-Tizon, A., and Mendez, J. 1994. Characterization of different chromatin types in Mytilus galloprovincialis L. after C-banding, fluorochrome and restriction endonuclease treatments. Heredity, 72: 242-249. 
Mendez, J., Pasantes, J.J., and Martinez-Exposito, M.J. 1990 Banding pattern of mussel (Mytilus galloprovincialis) chromosomes induced by $2 \times \mathrm{SSC} /$ Giemsa-stain treatment. Mar. Biol. 106: 375-377.

Menzel, R.W. 1974. Portuguese and Japanese oysters are the same species. J. Fish. Res. Board Can. 31: 45-50.

Mezzanote, R., Ferrucci, L., Vanni, R., et al. 1985. Some factors affecting the action of restriction endonucleases on metaphase chromosomes. Exp. Cell Res. 161: 247-253.

Nieddu, M., Rossino, R., Pichiri, G., Rocchi, M., Setzu, M.D., and Mezzanotte, R. 1999. The efficiency of in-situ hybridization on human chromosomes with alphoid DNAs is enhanced by previous digestion with AluI and TaqI. Chromosome Res. 7: 593602.

O'Foighil, D., and Taylor, D.J. 2000. Evolution of parental care and ovulation behaviour in oysters. Mol. Phylogenet. Evol. 15: 301-313.

O'Foighil, D., Gaffney, P.M., Wilbur, A.E., and Hilbish, T.J. 1998. Mithocondrial cytochrome oxidase I gene sequences support an Asian origin for the Portuguese oyster Crassostrea angulata. Mar. Biol. 131: 497-503.

Pieczarka, J.C., Nagamachi, C.Y., Muniz, J.A.P.C., Barros, R.M.S., and Mattevi, M.S. 1998. Analysis of constitutive heterochromatin of Aotus (Cebidae, Primates) by restriction enzyme fluorochrome bands. Chromosome Res. 6: 77-83.

Rodriguez-Romero, F., Laguarda-Figueras, A., Uribe-Alcocer, M., and Rojas-Lara, M.L. 1979. Distribution of "G" bands in the karyotype of Crassostrea virginica. Venus Jpn. J. Malacol. 38: 180-184.

Thiriot-Quiévreux, C. 1984. Analyse compare des caryotypes d'Ostreidae (Bivalvia). Cah. Biol. Mar. 25: 407-418.

Thiriot-Quiévreux, C. 1994. Advances in cytogenetics of aquatic organisms. In Genetics and evolution of aquatic organisms. Edited by A.R. Beaumont. Chapman and Hall, London, UK. pp. 369-388.

Thiriot-Quiévreux, C. 2002. Review of the literature on bivalve cytogenetics in the last ten years. Cah. Biol. Mar. 43: 17-26. Thiriot-Quiévreux, C., and Ayraud, N. 1982. Les caryotypes de quelques espèces de Bivalves et de Gastéropodes marins. Mar. Biol. 70: 165-172.

Wang, Y., and Guo, X. 2001. Chromosomal mapping of the vertebrate telomeric sequence (TTAGGG)N in four bivalve molluscs by fluorescence in situ hybridisation. J. Shellfish Res. 20: 11871190 . 


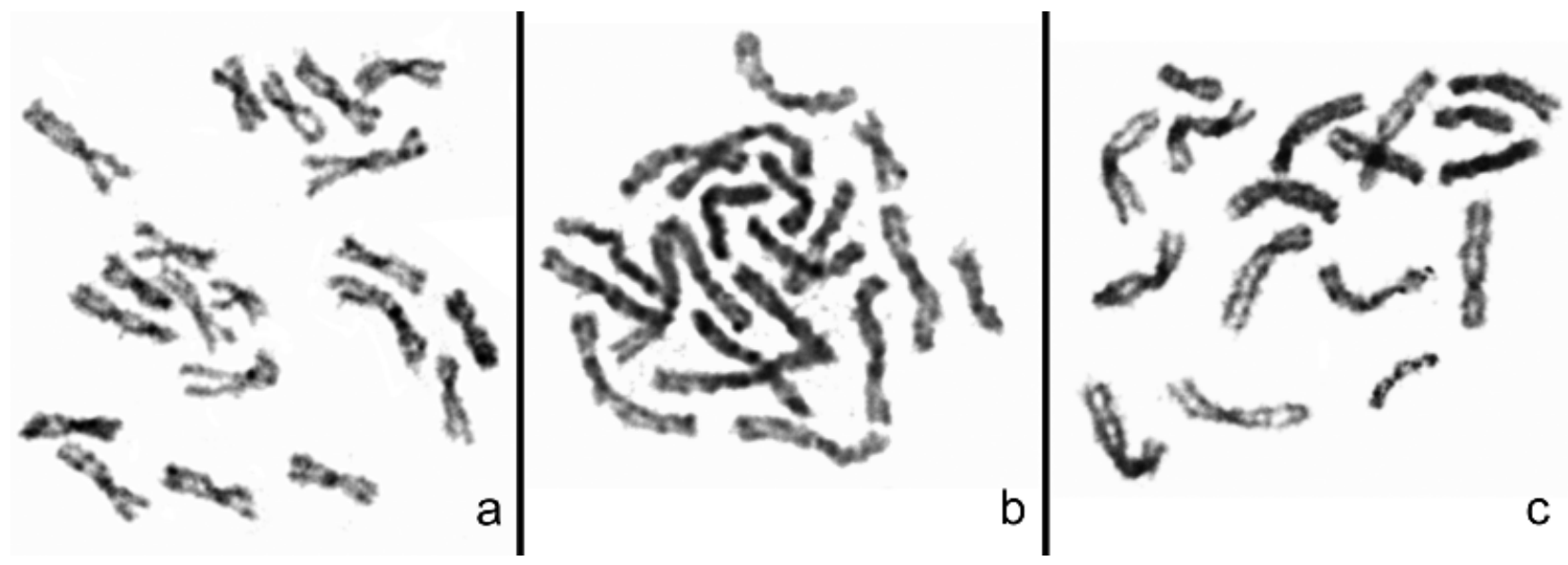

Fig. 1. Examples of banded metaphases with the three REs. (a) Metaphase of $C$. gigas banded with ApaI; $(b)$ metaphase of $C$. angulata banded with HaeIII; (c) metaphase of $O$. conchaphila banded with PstI.

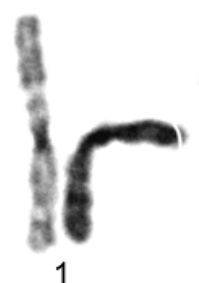

1

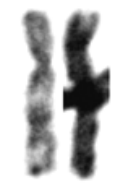

a 6

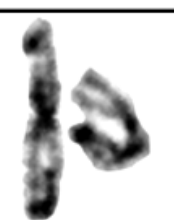

1

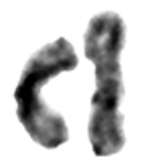

b
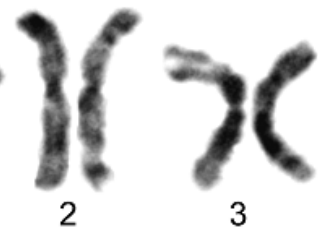

3

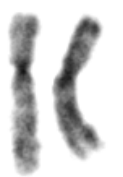

7

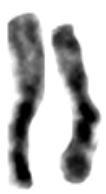

2

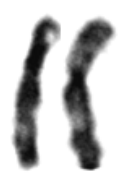

8

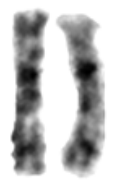

3
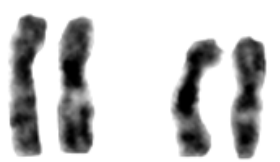

8

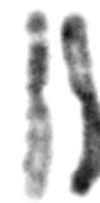

4
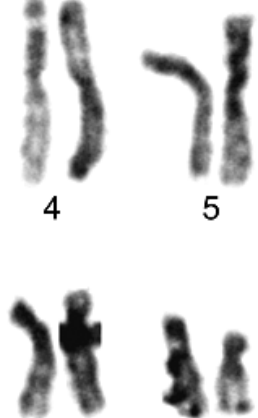

10

9

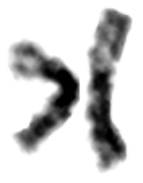

4

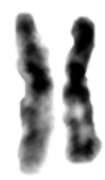

5

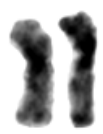

9

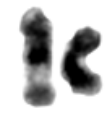

10
Fig. 2. Examples of two diploid banded karyotypes, (a) a diploid karyotype of $O$. edulis banded with ApaI and (b) a diploid karyotype of C. gigas banded with HaeIII. These examples are presented to show the banding pattern consistency between ho- mologous pairs. 


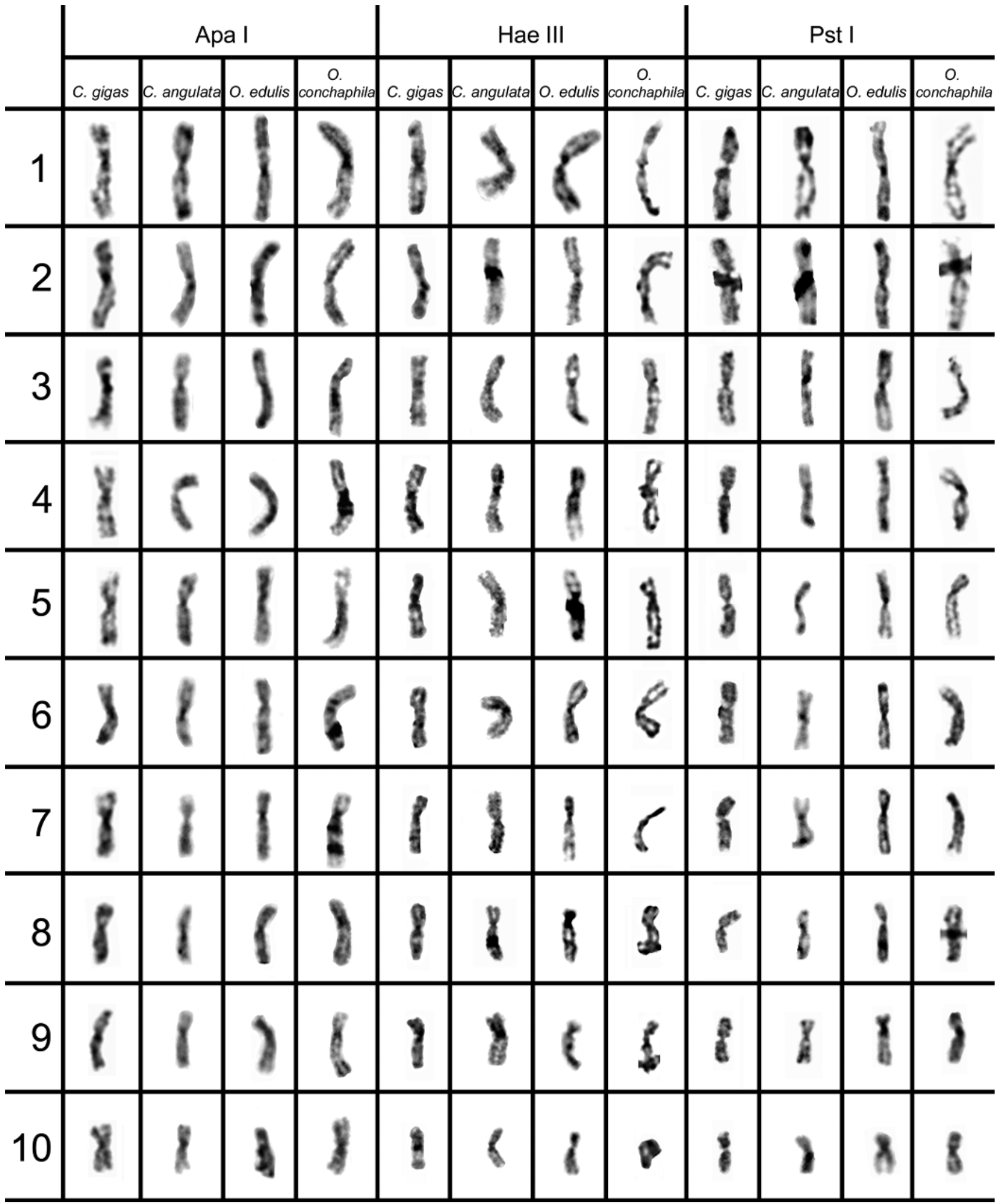

Fig. 3. Haploid distribution of chromosomal bands in the four oyster species for each of the three enzymes tested. 


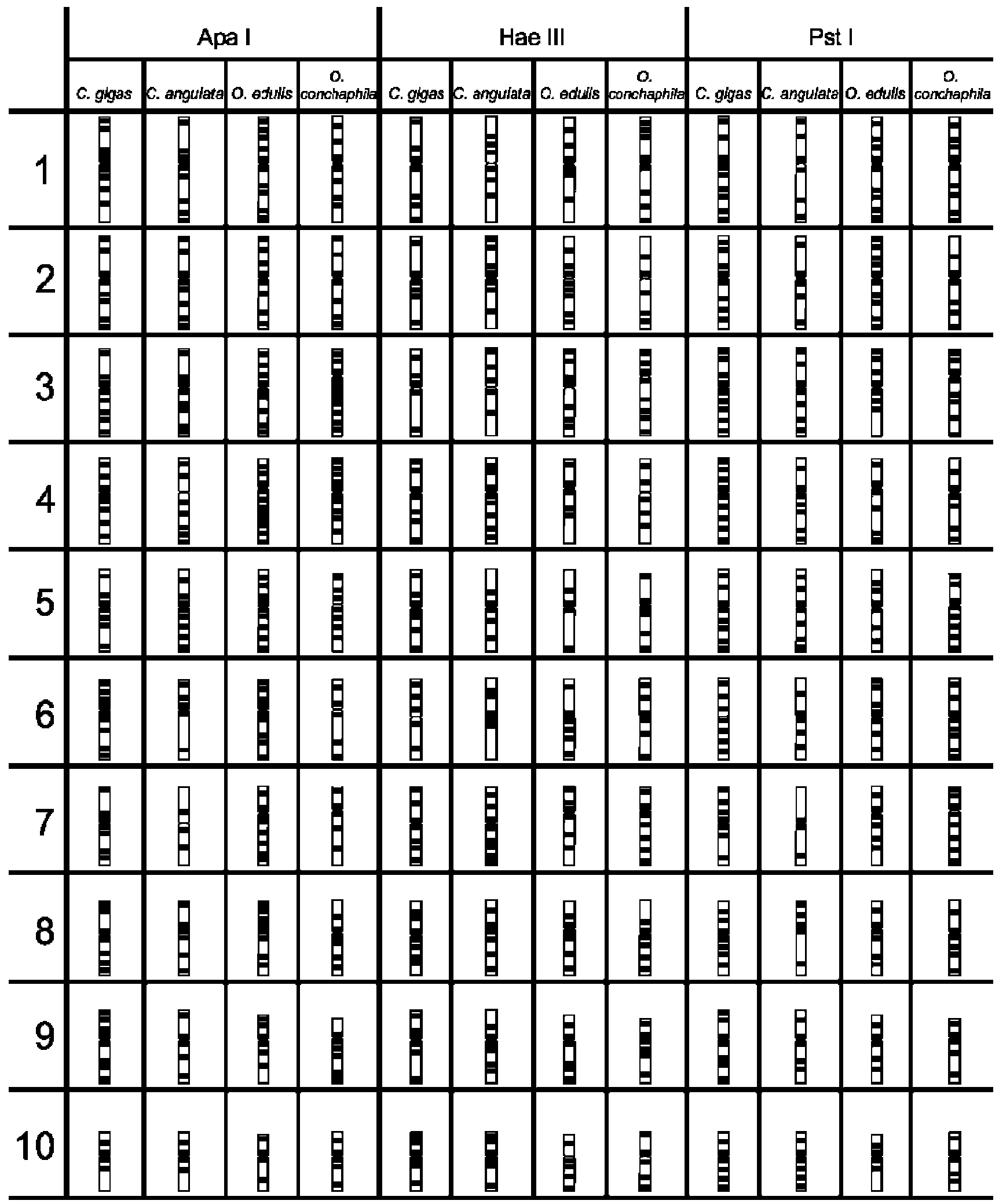

Fig. 4. Schematic representation of the in situ restriction banding patterns obtained for the three REs (ApaI, HaeIII, and PstI) in each one of the four oyster species. 